\title{
58
}

\section{PENANGANAN GIZI BURUK DENGAN PERSPEKTIF PERSON IN ENVIRONMENT OLEH PEKERJA SOSIAL}

\author{
Oleh: \\ Zulkarnain Bastari, Moch. Zainuddin, Nurliana Cipta Apsari
}

Email:

zulkarnainbastarii@gmail.com; moch.zainuddin@yahoo.com; nurliana.apsari@gmail.com

\begin{abstract}
ABSTRAK
Anak adalah aset dan generasi penerus bangsa. Anak harus mendapatkan hak-hak dan kewajiban sebagai seorang anak agar dapat tumbuh dan berkembang. Kesadaran masyarakat akan pola hidup sehat dan makan-makanan yang bergizi masih kurang. Person in environment memandang faktor penyebab gizi buruk berasal dari individu dan lingkungan. Indonesia memiliki jumlah penduduk terbesar ke 5 di dunia dengan jumlah penduduk 252.124.458 jiwa, jumlah penduduk miskin 28,53 juta orang dan hidup dilingkungan tidak sehat, dan setiap 5-6 juta bayi lahir di Indonesia, 75 - 85 persen berasal dari keluarga miskin, sekitar 1,67 juta jiwa menderita gizi buruk dan sekitar 10ribu anak meninggal akibat gizi buruk sehingga dibutuhkan intervensi khusus oleh pekerja sosial yang melihat dari person in evirenment untuk menanggulangi gizi buruk yaitu berupa pemberdayaan masyarakat miskin, penyadaran masyarakat akan pentingnya pola hidup sehat dan penguatan sektor pertanian.
\end{abstract}

Kata kunci: Gizi Buruk, Person In Envirenment, Pekerja Sosial

\section{Pendahuluan}

Banyaknya kasus meninggalnya anak balita gizi buruk banyak terjadi didaerah Indonesia. banyak hal yang menyebabkan anak balita gizi buruk. Seperti yang dikutip dari surat kabar online atcjehpos sebagai berikut:

Dua dari tujuh anak yang menderita gizi buruk di Kabupaten Aceh Utara dikabarkan meninggal dunia. Data tersebut merupakan hasil survey Dinas Kesehatan Aceh Utara terhitung awal Januari hingga awal November 2014. "Tahun ini terdapat tujuh kasus anak penderita gizi buruk. Satu kasus di Sawang, satu di Cot Girek, satu di Lhoksukon, satu di Matangkuli, satu di Samudera, dan tiga kasus di Syamtalira Bayu," ujar Kepala Dinas Kesehatan Aceh Utara, dr Effendi kepada ATJEHPOST.co, Rabu 12 November 2014. Ia menyebutkan dua penderita gizi buruk di Syamtalira Bayu sudah meninggal dunia. Meskipun angka tersebut masih tinggi, tapi terjadi penurunan dibandingkan tahun sebelumnya yang mencapai 21 kasus. "Untuk anak penderita gizi buruk lainnya kini kondisinya mulai membaik dan berat badan mulai naik. Selama enam bulan secara rutin kita berikan penyuluhan kepada ibunya, anaknya kita rawat dan kita berikan PMT (makanan tambahan) berupa susu, bubur, kacang hijau dan biscuit," katanya. Angka gizi buruk di Aceh Utara masih dipengaruhi oleh sejumlah faktor. Di antaranya faktor kemiskinan, dan minimnya pengetahuan orangtua dalam merawat anak. "Kita terus berupaya untuk menekan angka gizi buruk di Aceh Utara dengan memberikan penyuluhan ke desa-desa. Besar harapan untuk tahun mendatang kasus gizi buruk semakin berkurang," (http://atjehpost.co/m/read/14833/Tujuh-Anak-di-Aceh-Utara-DeritaGizi-Buruk-Dua-Meninggal-Dunia) Di unduh pada tanggal 17 desember 2014. 
Diketahui sampai saat ini gizi buruk masih terus terjadi di Indonesia sampai sekarang ini, terutama di daerah-daerah yang terpencil dan terplosok. Gizi buruk yaitu yang biasa kita kenal sebagai malnutrisi atau Kurang Energi Protein (KEP) yang dapat menyebabkan penyakit dan kematian pada anak-anak dan balita.

Gizi buruk di Indonesia mneurut kemenkes biasa di sebut dengan busung lapar atau Honger oedema disebabkan dari salah satu dari simtoma marasmus dan kwashiorkor. Gizi buruk disebabkan karena kekurangan protein kronis pada anak-anak yang sering disebabkan oleh beberapa hal, seperti anak atidak cukup mendapat makanan bergizi, anak tidak mendapat asupan gizi yang memadai dan anak menderita infeksi penyakit. selain itu bencana alam, daya beli masyarakat rendah, tingkat pendidikan, kondisi lingkungan dan pelayanan kesehatan yang rendah mempengaruhi gizi buruk.

Pekerja sosial memiliki peranan dalam mengembalikan keberfungsian sosial. Pekerja sosial memiliki tahapan-tahapan intervensi untuk mengurangi gizi buruk pada anak. Tahapan-tahapannya adalah assessment, plant of treatment treatment dan terminasi. Gizi buruk menurut Kleigmen et al, (2007) dibagi menjadi dua menurut yaitu malnutrisi primer dan malnutrisi sekunder.

Malnutrisi Primer adalah penyebab gizi buruk di daerah pedesaan atau daerah miskin lainnya sering disebut malnutrisi primer, yang disebabkan karena masalah ekonomi, rendahnya pengetahuan, dan kurangnya asupan gizi. Gejala kinis malnutrisi primer sangat bervariasi tergantung derajat dan lamanya kekurangan energi dan protein, umur penderita dan adanya gejala kekurangan vitamin dan mineral lainnya. Kasus tersebut sering dijumpai pada anak usia 9 bulan hingga 5 tahun. Pertumbuhan yang terganggu dapat dilihat dari kenaikkan berat badan terhenti atau menurun, ukuran lengan atas menurun, pertumbuhan tulang (maturasi) terlambat, perbandingan berat terhadap tinggi menurun. Gejala dan tanda klinis yang tampak adalah anemia ringan, aktifitas berkurang, kadang di dapatkan gangguan kulit dan rambut

Malnutrisi sekunder adalah gangguan pencapaian kenaikkan berat badan yang bukan disebabkan penyimpangan pemberian asupan gizi pada anak karena adanya gangguan pada fungsi dan sistem tubuh.Gangguan sejak lahir yang terjadi pada sistem saluran cerna, metabolisme, kromosom atau kelainan bawaan jantung, ginjal. Kasus gizi buruk di kota besar biasanya didominasi oleh malnutrisi sekunder.

\section{Gizi buruk pada Anak Indonesia}

Jumlah penduduk Indonesia yang tidak terkendali menimbulkan persoalan gizi buruk di kalangan anak-anak dan balita, karena jumlah penduduk yang tidak terkendali menjadikan permasalahan sosial seperti kemiskinan, pengangguran dan kriminalitas. Persoalan gizi buruk di sejumlah daerah di Indonesia, dari Sabang sampai Merauke mengkhawatirkan karena jumlah penderita gizi buruk yang masih tinggi dari setiap tahunnya. Hall ini harus menjadi perhatian serius, baik perhatian pemerintah maupun semua lapisan masyarakat.

Jumlah penduduk Indonesia 252.124.458 jiwa pada tahun 2013. Penduduk Indonesia hidup dibawah garis kemiskinan sebesar 28,553.930 orang, sekitar 11,25\% dan 20\% dari jumlah penduduk miskin adalah anak-anak dan setiap 5-6 juta bayi lahir di Indonesia, 75 - 85 persen berasal dari keluarga miskin. Dan sekitar 1,67 juta jiwa anak-anak menderita busung lapar

Perbandingan gizi kurang gizi buruk tahun 2007 dan 2013. Jumlahnya meningkat dari tahun 2007 hingga 2013. Yaitu sebagai berikut:

Secara nasional diperkirakan jumlah Prevalensi Balita Gizi Buruk dan Kurang sebesar 19,6\%. Jumlah ini jika dibandingkan dengan hasil Riskesdas tahun 2007, terjadi peningkatan yaitu dari 18,4\%. Bila 
dilakukan konversi ke dalam jumlah absolutnya, maka jumlah Balita pada tahun 2013 adalah 23.708.844, sehingga jumlah Balita Gizi buruk dan kurang sebesar 4.646.933 Balita.

Mengatasi gizi buruk pada anak balita, dibutuhkan pekerja sosial. pekerja sosial berperan dalam Peranan Fasilitatif, peranan Educational. Peranan-peranan Representasional, Peranan Teknis

Pekerjaan Sosial bertujuan untuk meningkatkan keberfungsian sosial individu-individu, baik secara individual maupun kelompok, dimana kegiatannya difokuskan kepada relasi sosial mereka khususnya interaksi orang-orang dengan lingkungannya. (Dalam Rex A. Skidmore, Milton Thackeray, dan O William Farley Introduction to Social Work, 1988 : 6, New Jersey: Simon \& Scuster Englewood Cliffs.)

Definisi peran menurut Kamus Bahasa Indonesia yang diterbitkan oleh Dinas Pendidikan Dan Kebudayaan (1997) adalah seperangkat tingkah yang diharapkan dimiliki oleh orang yang memiliki kedudukan di masyarakat. Dalam praktik pekerjaan sosial sebuah proses pemecahan masalah sesuai peran dan tujuan meliputi : assessment $\longrightarrow$ plan $\rightarrow$ intervention $\longrightarrow$ termination and evaluation.

Pekerja sosial melihat permasalahan diatas dilihat dari perspektif person in envirenment. Menurut Budhi Wibawa (2010:170), PIE adalah suatu metode untuk menggambarkan, mengklasifikasi dan mengkoding permasalahan-permasalahan pasien dan klien dewasa yang memperoleh pelayanan pekerja sosial. PIE adalah suatu holistic model system yang mengidentifikasi dan mengklasifikasi permasalahan-permasalahan klien atau pasien dalam keberfungsian sosial. Di dalamnya termasuk assessment mengenai individunya dan lingkungannya.

person in evnvironment (PIE) dalam suatu assessment fokusnya tidak hanya manusia tetapi juga system lingkungan yang berdampak pada kehidupannya. Pekerja sosial mengassesment penyebabpenyebab busung lapar dari perspektif person in environment. Pekerja sosial melihat kondisi ekonomi keluarga, pendidikan orang tua dan kondisi lingkungan

Kondisi ekonomi keluarga berpengaruh karena ekonomi berhubungan dengan pendapatan. pendapatan orangtua yang rendah menyebabkan sulitnya untuk mendapatkan pekerjaan yang layak sehingga daya beli dan akses terhadap makanan yang bergizi dan bermutu menjadi sulit, permasalahan tersebut berdampak kepada anak-anak dan balita. Anak-anak dan balita yang akan menjadi korban karena makan-makanan yang di beli orang tua tidak bergizi

Pendidikan orang tua yang rendah berpengaruh terhadap kesadaran masyarakat. kesadaran masyarakat akan pola hidup sehat dan pemilihan makan-makanan bergizi. Anak tidak mendapatkan makan-makanan yang bergizi membuat anak-anak dan balita tidak bisa menjadi anak-anak yang berbadan sehat. Hal itu karena anak-anak tidak mendapatkan makanan yang sehat dan menyehatkan. Kadar protein yang terkandung dalam makanan yang dikonsumsinya sangat minim dan berada di angka nol. Sangat wajar, apabila makanan yang masuk ke tubuhnya pun tidak memberikan dampak positif bagi perkembangan dan kemajuan seluruh sel tubuhnya untuk menjadi sehat.

Pekerja sosial melihat tidak adanya minuman yang mengandung zat-zat vitamin juga berdampak pada gizi buruk anak dan balita. Minumannya sangat jauh dari kadar-kadar vitamin. Selain itu, air yang digunakan untuk minum berasal dari air yang tidak bersih, karena sumbernya tidak bersih. hal itu, sangat dimungkinkan untuk menghambat kemajuan kesehatan anak-anak. lingkungan tempat tinggal yang tidak bersih, dapat menyebabkan sirkulasi udara menjadi tidak sehat, hal itu berdampak kepada kesehatan pernapasan anak-anak.

Pekerja sosial melihat kondisi lingkungan dan pelayanan kesehatan. Kondisi lingkungan tempat tinggal yang kurang sehat membuat penyakit akan mudah datang terhadap anak. Akses pelayanan kesehatan sangat penting karena penderita gizi buruk harus terus diawasi oleh medis 
mengenai nutrisi yang diterima. Biasanya anak yang menderita gizi buruk akan mudah terkenan penyakit.

Gizi buruk mengakibatkan kebodohan atau kurangnya tumbuh kembang otak yang dapat bersifat permanen dan tidak dapat terpulihkan. Jutaan anak dan balita tumbuh dengan kualitas rendah serta kehilangan masa emas.

Seharusnya nutrisi kepada anak harus tercukupi dengan memberikan makanan yang bergizi berupa sayur mayur, buah-buahan, makanan yang mengandung karbohidrat dan protein. Selain itu setiap balita yang baru lahir wajib diberikan asi ekslusif selama 6 bulan untuk memenuhi nutrisinya.

Nutrisi pada anak harus terpenuhi karena anak merupakan aset bangsa, generasi dan penerus cita-cita bangsa. Oleh karena itu setiap anak mempunyai hak-hak untuk dapat tumbuh, berkembang, bebas dari kekerasan dan diskriminasi. Akan tetapi masih banyak anak yang tidak mendapatkan haknya karena menderita gizi buruk. Anak tidak dapat menyelesaikan task-task pada masa perkembangannya. Anak menjadi kelangsungan hidup bangsa dan negara. Indoensia bergantung pada kualitas penerus bangsa. Namun masih banyak anak yang menderita gizi buruk. Anak sebagai generasi penerus bangsa bisa terhambat perkembangannya karena dampak yang dapat ditimbulkan oleh gizi buruk.

Pekerja sosial dalam tahapan plan of treatment melihat dari assessment yang dilakukan. Plan of treatment yang dilakukan adalah memberdayakan masyarakat meskin, menyadarkan masyarakat akan hidup sehat, mempermudah akses terhadap pelayanan sosial, kebijakan untuk masyarakat dan pertanian untuk keberlanjutan pang masyarakat.

Pemberdayaan masyarakat menurut edi suharto merupakan salah satu metode atau pendekatan inti yangmenunjukan keunikan pekerja sosial. pekerja sosial menfokuskan kepada keberfungsian klien dalam konteks organisasi, masyarakat dan kebijakan untuk menyelesaikan masalah-masalah dan isu-isu yang berkaitan dengan kehidupan individu dan kelompok.

Pekerja sosial menintervensi masyarakat miskin dengan memusatkan kepada pemberdayaan masyarakat miskin, misalnya dengan pelatihan atau program padat karya dan meningkatkan taraf hidup masyarakat, seperti dibukanya akses lapangan pekerjaan, dengan adanya lapangan pekerjaan, masyarakat akan mudah untuk memperoleh pekerjaan dan memiliki pendapatan. Masyarakat juga akan bisa memanfaatkan hasil pendapatannya untuk membeli makanan dan minuman yang sehat dan bergizi.

Membuat pelayanan kesehatan yang mudah diakses rakyat kecil, seperti puskesmas dan posyandu dan program-program pemberian makanan tambahan. Pelayanan posyandu yang diselenggarakan pemerintah harus mendapat dukungan sepenuhnya dari masyarakat. Pemerintah memberikan pemberdayaan kepada kader-kader posyandu. Kader adalah anggota masyarakat yang diberi keterampilan untuk dapat menjalankan posyandu, peran masyarakat sangat penting dalam melibatkan organisasi seperti karang taruna, LKMD dan PKK, untuk memperluas jaringan posyandu. Melalui posyandu, pemerintah ingin menciptakan masyarakat sehat dengan pembangunan kesadaran mengenai arti pentingnya masalah gizi terhadap kesehatan kepada masyarakat secara adil dan merata. hal tersebut telah dibuktikan dengan adanya posyandu gratis, dan penyuluhan terhadap ibu hamil dan balita Menuju Sehat.

Mengubah arah kebijakan publik agar segala kebijakannya pertama-tama adalah kepentingan rakyat/umum (public oriented). Pemerintah mengubah arah kebijakannya dari yang sekadar emergensi dengan pendekatan jangka pendek menjadi pendekatan jangka panjang serta mengambil kebijakan publik yang memberikan hak-hak masyarakat atas pembangunan. Hal ini bisa dilakukan dengan

Pekerja sosial menyadarkan masyarakat terhadap kesehatan lingkungan dan menyadarkan pola hidup sehat. Penyadaran pola hidup sehat membuat masyarakat memilih makan-makanan yang bergizi dan sehat. 
Pekerja sosial bisa menerapkan atau mengaplikasikan pemberdayaan tekhnologi pertanian yang tepat yang sesuai dengan kondisi alam di setiap daerah. Di samping itu, perlu juga mengembangkan komoditi yang merupakan kelebihan atau keunggulan dari daerah tersebut, misalnya mengembangkan peternakan dengan membagikan 'pinjaman' bibit hewan dengan bunga lunak.

Pekerja sosial saat terminasi tetap dalam kerangka jangka panjang sehingga tidak membuat rakyat menjadi tergantung. Dari sisi pemerintah sendiri, hendaknya prinsip good government benarbenar diperhatikan dan dilaksanakan.

Mencuatnya kasus-kasus gizi buruk juga sangat berkaitan erat dengan faktor budaya yang ada di masyarakat kita. Selama ini masih banyak budaya di masyarakat kita yang kurang mendukung kesadaran tentang pentingnya gizi anak. Oleh karena itu, sudah saatnya budaya yang menyimpang harus kita ubah dan meluruskan pandangan masyarakat selama ini apabila kita semua tidak ingin kehilangan generasi penerus bangsa.

\section{Kesimpulan}

Masalah gizi buruk mempunyai dimensi yang sangat luas, baik dari konsekuensinya terhadap penurunan kualitas sumberdaya manusia maupun faktor penyebab. Gizi buruk secara langsung maupun tidak langsung akan menurunkan kecerdasan anak, mengganggu pertumbuhan dan perkembangan serta menurunkan produktivitas. Dari aspek penyebab, gizi buruk sangat terkait dengan kondisi daya beli keluarga, tingkat pendidikan dan pola asuhan gizi keluarga serta keadaan kesehatan.

Menyelesaikan permasalahan kematian Anak akibat gizi buruk, sangat diperlukan keterlibatan pemerintah dan lapisan masyarakat untuk mengelola penanganan anak gizi buruk. sehingga diharapkan semua kasus gizi buruk dapat ditangani dengan baik.

Penanggulangan gizi buruk tidak dapat melibatkan satu sector saja yaitu sektor kesehatan, tetapi semua sector. Pekerja sosial melihat gizi buruk dari person in environment. Sehingga dalam penyelesaian masalah gizi buruk perlu dilakukan pemberdayaan masyarakat, penyadaran masyarakat dan peningkatan sekto pangan.

\section{Daftar Pustaka}

Skidmore.1987.Introduction to Social Work Sixth Edition. Prentice Hall International Edition

Wibawa, Budhi, et al.2010.Dasar-dasar Pekerjaan Sosial. Widya Padjadjaran:Bandung

Rex A. Skidmore, Milton Thackeray, dan O William Farley Introduction to Social Work, New Jersey: Simon \& Scuster Englewood Cliffs

Itasca, Illinois Social Work Practice: Model and Methode, Peacock Publishers

Soejanto, Agoes. 2005. Psikologi Perkembangan. Jakarta: PT Rineka Cipta

KPAI. 2007, Jalan Terjal Menujun Kepentingan Terbaik Bagi Anak. Jakarta

RISKESDES 2013, Kementrian Kesehatan Republik Indonesia 2006

Suahrto, Edi, Pengembangan masyarakat dalam praktek pekerjaan sosial

Risk Factors of Protein Energy Malnutrition "Kwashiorkor and Marasmus" among Children Under Five Years of Age in Assiut University Children Hospital

Rencana Aksi Nasional dalam Pencegahan dan Penanggulanagan Gizi Buruk Tahun 2005 - 2009, Kementrian Kesehatan RI 
Pedoman Pelayanan Anak Gizi Buruk 2011, Kementrian Kesehatan RI

Jeffrey R. EdwardsKenan-Flagler Research, Person-Environment Fit Theory: Conceptual Foundations, Empirical Evidence, and Directions for Future, Business School University of North Carolina

http://www.bps.go.id/getfile.php?news=1070

http://atjehpost.co/m/read/14833/Tujuh-Anak-di-Aceh-Utara-Derita-Gizi-Buruk-Dua-Meninggal$\underline{\text { Dunia }}$ 